\title{
Analisis Faktor Penyebab $C C O$ dan Pengaruhnya Terhadap Biaya Kontraktor Pada Proyek Jalan Tol
}

\author{
Zentenno $^{1, *}$, Agus Suroso ${ }^{1}$ \\ Program Studi Magister Teknik Sipil, Universitas Mercu Buana, Jakarta ${ }^{1}$ \\ Koresponden*, Email: zen.tenno@yahoo.com
}

\begin{tabular}{|c|c|c|}
\hline & Info Artikel & Abstract \\
\hline Diajukan & 28 Jumi 2021 & This case study showed a $54 \%$ increase in Contract Change Order (CCO) work against the \\
\hline Diperbaiki & 24 Juli 2021 & initial contract fee. The purpose of this study was to determine the factors that cause the \\
\hline Disetujui & 24 Juli 2021 & $\begin{array}{l}\text { occurrence of } C C O \text {, the influence of } C C O \text { on the contractor cost performance, and how much } \\
C C O \text { affecting the contractor costs performance on toll road projects. The research method } \\
\text { was using survey methods and data are processed with multiple linear regression. The results } \\
\text { of this research shows that CCO work has the impact of increasing costs because of several } \\
\text { factors such as contract documents, stakeholders, design, and construction. The most } \\
\text { dominant variables that increase in costs were construction variables with a test value of } 2,830 \text {, }\end{array}$ \\
\hline $\begin{array}{l}\text { Keywords: } \\
\text { Contract Cl } \\
\text { Regression, }\end{array}$ & $\begin{array}{l}\text { and Effect Analysis, } \\
\text { Order, Multiple Linear }\end{array}$ & $\begin{array}{l}\text { a significant value of } 0.007 \text {, and a regression coefficient of } 0.103 \text {. This research greatly } \\
\text { influenced the performance of costs on toll road works by } 80.9 \% \text { of the remaining } 19.1 \% \\
\text { described by other variables beyond the regression model analyzed. }\end{array}$ \\
\hline
\end{tabular}

Contract Change Order, Multiple Linear Regression, Cost

Kata kunci: Analisis Penyebab dan Pengaruh, Contract Change Order, Regresi Linier Berganda, Biaya

\begin{abstract}
Abstrak
Studi kasus ini menunjukkan terjadinya peningkatan pekerjaan contract change order (CCO) sebesar $54 \%$ terhadap biaya kontrak awal. Tujuan riset ini adalah untuk mengetahui faktor penyebab terjadinya $\mathrm{CCO}$, mengetahui pengaruh $C \mathrm{CO}$ pada kinerja biaya kontraktor, dan seberapa besar pengaruh $C C O$ terhadap kinerja biaya kontraktor pada proyek jalan tol. Metode riset menggunakan metode survey dan data diolah dengan regresi linier berganda. Hasil riset ini menunjukkan bahwa pekerjaan $C C O$ berpengaruh terhadap peningkatan biaya karena berbagai faktor seperti dokumen kontrak, stakeholder, desain, dan konstruksi. Variabel terpenting yang mempengaruhi kenaikan biaya adalah variabel konstruksi dengan nilai uji-T sebesar $\mathbf{2 , 8 3 0}$, nilai signifikan yaitu 0,007 , dan koefisien regresi sebesar 0,103 . Riset ini sangat mempengaruhi secara simultan terhadap kinerja biaya pada pekerjaan jalan tol sebesar $80,9 \%$, sisanya $19,1 \%$ didapat dari luar model variabel pada regresi yang telah dianalisis.
\end{abstract}

\section{Pendahuluan}

Pertumbuhan ekonomi di Indonesia secara bertahap mulai meningkat sejak krisis ekonomi yang melanda pada tahun 1990. Data terakhir menunjukkan bahwa dari tahun 2015 hingga 2018 pertumbuhan ekonomi Indonesia mengalami peningkatan yang konsisten dan masih dipertahankan pada level 5\% [1].

Contract change order merupakan perubahan dalam lingkup kontrak, konfirmasi akan revisi penjadwalan, kumpulan dari modifikasi-modifikasi lain dan berupa standard formulir yang meliputi ringkasan dari deskripsi perubahan dan dampak dari perubahan tersebut terhadap kontrak, baik waktu dan biaya proyek [2]. Penyebab terjadinya contract change order bisa disebabkan oleh banyak faktor. Dalam setiap proyek konstruksi penyebab dari terjadinya contract change order tidak pernah sama, dan tidak akan pernah sama [3]. Salah satu permasalahan dari pekerjaan jalan tol pada ruas pejagan pemalang yaitu terjadinya pekerjaan tambah kurang atau biasa dikenal dengan istilah contract change order $(\mathrm{CCO})$ terhadap nilai kontrak yang akan dikerjakan khususnya pada pembangunan jalan tol proyek strategis nasional (PSN).

Riset sebelumnya menyatakan pembangunan konstruksi di Florida terjadi penambahan nilai kontrak 5-10\% yang disebabkan oleh contract change order, riset pada penelitian terdahulu telah menganalisis sebelas dari variabel yang berdampak pada biaya pembangunan, waktu serta kondisi proyek menjadi penyebab yang sangat penting pada pekerjaan contract change order [2]. Faktor penyebab contract change order sangat beragam dan unik, setiap proyek memiliki penyebab yang berbeda antara satu proyek dengan yang lainnya. Faktor penyebab contract change order dapat disebabkan oleh pengguna jasa maupun penyedia [4]. Studi kasus pembangunan jalan Kegubernuran Kirkuk di Irak penambahan biaya sebesar 28,8\% karena menambahkan pekerjaan beton untuk dinding penyangga untuk menghadirkan area rendah dan tinggi di kedua sisi jalan baru karena mengekspos jalan [5]. Berdasarkan riset 
terdahulu mengungkapkan bahwa peneliti menelaah data 161 pembangunan transportasi yang sudah selesai, hasil yang diperoleh $95 \%$ serta $100 \%$ dari pembangunan jalan dan kereta api, memiliki kenaikan biaya 50\% [6]. Studi tentang Joint Komisi Pemeriksa dan Peninjau Legislatif (JLARC) tentang 300 proyek pembangunan jalan di Virginia mengungkapkan bahwa perubahan proyek rata-rata lebih dari $11 \%$ [7]. Berdasarkan riset terdahulu permintaan perubahan telah menyebabkan pembengkakan biaya dengan kenaikan rata-rata sebesar 9,9\% dari nilai kontrak awal [8]. Berdasarkan riset terdahulu $C C O$ memiliki lima efek yang paling umum, yaitu: peningkatan biaya proyek, peningkatan durasi aktivitas untuk setiap item pekerjaan, jadwal penyelesaian pekerjaan yang tertunda, anggaran tambahan untuk kontraktor, dan pembayaran yang tertunda [9]. Fenomena yang terjadi pada proyek studi kasus riset ini telah melakukan pekerjaan contract change order dengan peningkatan total keseluruhan dari pekerjaan contract change order (CCO) sebesar 54\% terhadap biaya kontrak awal.

Berdasarkan riset terdahulu dan fenomena yang ada pada studi kasus peneliti memiliki tujuan kajian ilmiah ini untuk mengetahui faktor apa saja yang ada pada contract change order (CCO) sehingga menjadi penyebab dominan terjadinya, untuk mengetahui pengaruh contract change order pada kinerja biaya kontraktor pekerjaan jalan tol, dan untuk mengetahui pengaruh secara simultan pada contract change order terhadap biaya kontraktor pembangunan pekerjaan jalan tol.

\section{Metode}

Riset dilakukan pada studi kasus jalan tol ruas pejagan pemalang. Setelah dilakukannya observasi lapangan keproyek tersebut, diperoleh informasi mengenai jumlah sampel dari keseluruhan proyek tersebut ada 52 orang. Persyaratan atau kriteria yang akan ikut serta dalam riset ini yaitu responden yang berhubungan langsung dengan pembangunan ruas jalan tol seperti dari pihak pengguna jasa, penyedia jasa, dan konsultan baik konsultan pengawas maupun perencana. Berdasarkan riset terdahulu menyatakan bahwa semakin besar contoh dari populasi saat ini, semakin baik, namun ada angka dasar yang harus diambil oleh para ilmuwan, khususnya di atas 30 sampel [10].

Variabel dalam penelitian ini ada empat hal pokok dari penyebab pekerjaan tambah kurang / contract change order yaitu dokumen kontrak, stakeholder, desain, dan konstruksi. terhadap biaya. Desain dalam riset ini terdiri dari data primer dan data sekunder. Data primer adalah sumber informasi yang secara langsung memberikan informasi kepada otoritas informasi sedangkan data sekunder adalah sumber informasi yang tidak langsung memberikan informasi kepada pengumpul informasi [11]. Sumber data pada riset yang akan dilakukan ini terdiri dari 2 (dua) yaitu :

1. Data Primer yang akan dilakukan yaitu riset metode survey, data tersebut diperoleh dari hasil pengumpulan kuesioner pada ketiga pihak responden yang ikut serta dalam pembangunan seperti konsultan, penyedia jasa, serta pengguna jasa.

2. Data Sekunder untuk riset metode survey diperoleh dari studi literatur diantaranya yaitu website, buku, jurnal riset terdahulu.

Metode survey yang dilakukan yaitu pengumpulan data riset dengan cara menyebarkan isi kuesioner kepada pihak site manager, quantity surveyor, staf teknik, dan staf keuangan, pengawas lapangan untuk mendapatkan informasi mengenai penyebab dan pengaruhnya terhadap biaya pada pembangunan jalan tol. Penyebaran daftar pertanyaan atau kuesioner dilakukan dengan mendatangi langsung pada proyek konstruksi dan menggunakan google form pada jalan tol ruas pejagan pemalang. Setelah observasi dilakukan, maka diperoleh sampel pada objek riset yaitu 52 responden.

Metode analisis data riset ini menggunakan uji regresi linier berganda. Pengujian yang dijalankan dimulai dengan uji validasi, uji reliabilitas, uji asumsi klasik, kemudian uji regresi linier berganda, uji-t, kemudian uji-f. Apabila instrument riset dinyatakan valid, dan reliabel langkah berikutnya yaitu melakukan, pengujian pada asumsi klasik. Pengujian asumsi klasik meliputi beberapa uji normalitas, multikolinearitas, heteroskedastisitas, dan autokorelasi. Setelah instrument riset dinyatakan sesuai dengan ketentuan selanjutnya yaitu melakukan uji, regresi linier berganda. Riset ini terdiri dari pengujian korelasi koefisien, dan determinasi koefisien. Pengujian berikutnya hipotesis, riset ini dilakukan dengan cara menggunakan, Uji-T berguna untuk mengetahui pengaruh variabel bebas, untuk menjelaskan variasi variabel terikat secara individual, dan untuk riset uji-f.

\section{Hasil dan Pembahasan}

Keterbaruan (state of the art) pada riset ini yaitu membahas mengenai faktor-faktor penyebab terbitnya contract change order dan pengaruhnya terhadap biaya kontraktor pada pekerjaan jalan tol studi kasus ruas pejagan pemalang yang memliki target proyek strategis nasional (psn) dengan dibantu menggunakan simulasi tools Microso$\mathrm{ft}$ Excel dan Statistical Package for the Social Sciences (SPSS). 
Tabel 1. Variabel Bebas (X)

\begin{tabular}{|c|c|c|}
\hline Variabel & & Indikator \\
\hline \multirow{5}{*}{$\begin{array}{l}\text { Dokumen } \\
\text { Kontrak } \\
\text { (X1) }\end{array}$} & $\mathrm{X} 1.1$ & $\begin{array}{l}\text { Pasal tentang contract change } \\
\text { order tidak dituangkan pada }\end{array}$ \\
\hline & $\mathrm{X} 1.2$ & $\begin{array}{l}\text { kontrak konstruksi secara jelas. } \\
\text { Spesifikasi teknis yang tidak } \\
\text { dituangkan jelas pada RKS, bill } \\
\text { of quantity dan gambar tender. }\end{array}$ \\
\hline & $\mathrm{X} 1.3$ & $\begin{array}{l}\text { Penambahan atau pun } \\
\text { pengurangan item pekerjaan }\end{array}$ \\
\hline & $\mathrm{X} 1.4$ & $\begin{array}{l}\text { Item pekerjaan tambah tidak } \\
\text { tercantum dalam kontrak }\end{array}$ \\
\hline & $\mathrm{X} 1.5$ & Proses pengadaan yang buruk \\
\hline \multirow{4}{*}{$\begin{array}{l}\text { Variabel } \\
\text { Stakeholder } \\
(\mathrm{X} 2)\end{array}$} & & Indikator \\
\hline & $\mathrm{X} 2.1$ & $\begin{array}{l}\text { Permintaan pemilik proyek } \\
\text { (owner) untuk optimalisasi fungsi } \\
\text { bangunan. }\end{array}$ \\
\hline & $\mathrm{X} 2.2$ & $\begin{array}{l}\text { Pemilik menginstruksikan } \\
\text { pekerjaan tambahan }\end{array}$ \\
\hline & $\mathrm{X} 2.3$ & $\begin{array}{l}\text { Keterlambatan owner dalam } \\
\text { menyetujui gambar, desain } \\
\text { kontrak dan klarifikasi }\end{array}$ \\
\hline \multirow{6}{*}{$\begin{array}{c}\text { Variabel } \\
\text { Desain (X3) }\end{array}$} & & Indikator \\
\hline & $\mathrm{X} 3.1$ & $\begin{array}{l}\text { Ketidaksesuaian antara gambar } \\
\text { dan kondisi lapangan. }\end{array}$ \\
\hline & $\mathrm{X} 3.2$ & $\begin{array}{l}\text { Detail gambar tender awal yang } \\
\text { kurang lengkap/ kurang jelas. }\end{array}$ \\
\hline & $\mathrm{X} 3.3$ & $\begin{array}{l}\text { Perubahan desain / design } \\
\text { changes }\end{array}$ \\
\hline & $\mathrm{X} 3.4$ & $\begin{array}{l}\text { Perbedaan volume yang cukup } \\
\text { signifikan antara gambar, kondisi } \\
\text { lapangan dan bill of quantity }\end{array}$ \\
\hline & $\mathrm{X} 3.5$ & $\begin{array}{l}\text { Keterlambatan dalam persetujuan } \\
\text { shopdrawing oleh pihak } \\
\text { konsultan dan owner. }\end{array}$ \\
\hline Variabel & & Indikator \\
\hline \multirow{8}{*}{$\begin{array}{l}\text { Konstruksi } \\
\text { (X4) }\end{array}$} & $\mathrm{X} 4.1$ & Kesalahan metode kerja \\
\hline & $\mathrm{X} 4.2$ & $\begin{array}{l}\text { Keterlambatan pengiriman } \\
\text { material dan alat kerja. }\end{array}$ \\
\hline & $\mathrm{X} 4.3$ & Modifikasi spesifikasi material \\
\hline & $\mathrm{X} 4.4$ & $\begin{array}{l}\text { Perubahan cakupan / scope } \\
\text { changes }\end{array}$ \\
\hline & $\mathrm{X} 4.5$ & $\begin{array}{l}\text { Kesalahan dalam menghitung } \\
\text { estimasi volume }\end{array}$ \\
\hline & $\mathrm{X} 4.6$ & Naikkan harga kontrak \\
\hline & $\mathrm{X} 4.7$ & $\begin{array}{l}\text { Peningkatan penyelidikan kondisi } \\
\text { tanah }\end{array}$ \\
\hline & $\mathrm{X} 4.8$ & Pemindahan lokasi quarry \\
\hline
\end{tabular}

Hasil riset akan dilakukan dengan cara menganalisa persetujuan atau validasi penggunaan variabel bebas $(\mathrm{X})$ melalui 5 (lima) pakar yang memliki kompeten di bidangnya untuk mengetahui variabel-variabel sesuai atau tidak sesuai. Tabel 1 Menjelaskan mengenai variabel bebas dari riset yaitu penyebab terjadinya contract change order.

Hasil persepsi validasi penggunaan varibel bebas (X) dari 5 (lima) pakar didapatkan beberapa indikator variabel yang dikeluarkan karena menurut para pakar kurang sesuai. Indikator tersebut yaitu: X.1.1, X.4.1, X.4.2, X.4.7, dan X.4.8 sehingga terdiri 16 indikator variabel yang tersisa.

Riset selanjutnya dilakukan penyebaran kuesioner kepada pihak responden yang ikut serta dalam pembangunan jalan tol sebanyak 52 buah kuesioner, diantaranya pihak penyedia jasa, pengguna jasa, serta konsultan baik itu pengawas maupun perencana. Data penyebaran kuesioner pada Gambar 1

\section{Jumlah Responden}

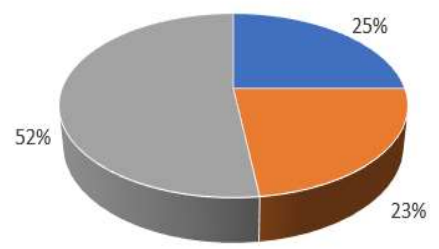

- Konsultan -Pemilik Pekerjaan/Pengguna Jasa/Owner - Penyedia Jasa/Kontraktor

Gambar 1. Jumlah Responden

Riset selanjutnya dilakukan pengujian validitas dan reabilitas dengan menggunakan SPSS. Uji validitas dilihat dari harga koneksi r Pearson yang memenuhi syarat, dimana $r$ hitung lebih besar dari $r$ tabel dan nilai kritis (2-tailed) dibawah 0,05 [2]. Data indikator variabel yang terdiri dari 16 buah dan variabel $\mathrm{X}$ yang terdiri dari 4 buah dinyatakan valid.

Uji reliabilitas dengan menggunakan SPSS, pengujian riset Cronbach Alpha yaitu 0,946 atau lebih dari ketentuan sebesar 0.6, maka riset yang dilakukan dinyatakan reliabel. Riset variabel teruji valid dan reliabel pada resume Tabel 2.

Pengujian selanjutnya menggunakan asumsi klasik, uji normalitas pada riset ini didapatkan hasil suatu model regresi berdistribusi normal karena data pada ploting (titik-titik) yang menggambarkan keadaan dari sesungguhnya mengikuti garis diagonal [12]. Hasil riset pada Gambar 2.

Pengujian pada riset selanjutnya yaitu asumsi klasik uji multikolinieritas dengan menggunakan suatu besaran pada VIF (Variance Inflation Factor). Suatu pengujian riset tida$\mathrm{k}$ akan terjadi multikolinieritas jika nilai tolerance $>0,100$ serta jika nilai VIF $<10,00$ [12]. 
Tabel 2. Variabel Valid dan Reliabel

\begin{tabular}{|c|c|c|}
\hline Variabel & & Indikator \\
\hline \multirow[t]{4}{*}{$\begin{array}{l}\text { Dokumen } \\
\text { Kontrak } \\
\text { (X1) }\end{array}$} & $\mathrm{X} 1.2$ & $\begin{array}{l}\text { Spesifikasi teknis yang tidak } \\
\text { dituangkan jelas pada RKS, bill } \\
\text { of quantity dan gambar tender. }\end{array}$ \\
\hline & $\mathrm{X} 1.3$ & $\begin{array}{l}\text { Penambahan ataupun } \\
\text { pengurangan item pekerjaan }\end{array}$ \\
\hline & $\mathrm{X} 1.4$ & $\begin{array}{l}\text { Item pekerjaan tambah tidak } \\
\text { tercantum dalam kontrak }\end{array}$ \\
\hline & $\mathrm{X} 1.5$ & Proses pengadaan yang buruk \\
\hline Variabel & & Indikator \\
\hline \multirow[t]{3}{*}{$\begin{array}{l}\text { Stakeholder } \\
(\mathrm{X} 2)\end{array}$} & $\mathrm{X} 2.1$ & $\begin{array}{l}\text { Permintaan pemilik proyek } \\
\text { (owner) untuk optimalisasi fungsi } \\
\text { bangunan. }\end{array}$ \\
\hline & $\mathrm{X} 2.2$ & $\begin{array}{l}\text { Pemilik menginstruksikan } \\
\text { pekerjaan tambahan }\end{array}$ \\
\hline & $\mathrm{X} 2.3$ & $\begin{array}{l}\text { Keterlambatan owner dalam } \\
\text { menyetujui gambar, desain } \\
\text { kontrak dan klarifikasi }\end{array}$ \\
\hline Variabel & & Indikator \\
\hline \multirow[t]{6}{*}{ Desain (X3) } & $\mathrm{X} 3.1$ & $\begin{array}{l}\text { Ketidaksesuaian antara gambar } \\
\text { dan kondisi lapangan. }\end{array}$ \\
\hline & X3.2 & $\begin{array}{l}\text { Detail gambar tender awal yang } \\
\text { kurang lengkap/ kurang jelas. }\end{array}$ \\
\hline & $\mathrm{X} 3.3$ & $\begin{array}{l}\text { Perubahan desain / design } \\
\text { changes }\end{array}$ \\
\hline & X3.4 & $\begin{array}{l}\text { Perbedaan volume yang cukup } \\
\text { signifikan antara gambar, kondisi } \\
\text { lapangan dan bill of quantity }\end{array}$ \\
\hline & $\mathrm{X} 3.5$ & $\begin{array}{l}\text { Keterlambatan dalam persetujuan } \\
\text { shopdrawing oleh pihak }\end{array}$ \\
\hline & & konsultan dan owner. \\
\hline Variabel & & Indikator \\
\hline \multirow{4}{*}{$\begin{array}{l}\text { Konstruksi } \\
\text { (X4) }\end{array}$} & $\mathrm{X} 4.3$ & Modifikasi spesifikasi material \\
\hline & $\mathrm{X} 4.4$ & $\begin{array}{l}\text { Perubahan cakupan / scope } \\
\text { changes }\end{array}$ \\
\hline & $\mathrm{X} 4.5$ & $\begin{array}{l}\text { Kesalahan dalam menghitung } \\
\text { estimasi volume }\end{array}$ \\
\hline & $\mathrm{X} 4.6$ & Naikkan harga kontrak \\
\hline
\end{tabular}

Coefficient yang terjadi pada Tabel 3 dapat dilihat VIF nilai tersebut ada di bawah 10 yaitu $(X .1=3,202, X .2=$ 2,675, X.3 = 3,160 dan X.4 =2,404). Demikian juga nilai pada tolerance berada jauh di atas 0,10 yaitu sebesar $(\mathrm{X} .1=$ $0,312, X .2=0,374, X .3=0,316$ dan X.4 =0,416). Riset ini didapatkan model regresi tidak mengalami multikolinearitas.
Asumsi klasik uji heterokedastisitas tidak akan terjadi, jika tidak terdapat suatu pola yang jelas yaitu (bergelombang, melebar kemudian menyempit) pada gambar scatterplots, dan suatu titik-titik terdistribusi di atas dan di bawah nol pada sumbu Y [12]. Hasil riset pada Gambar 3.

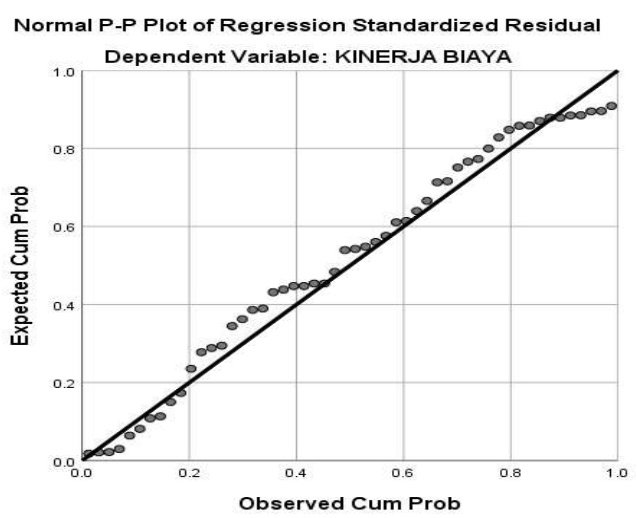

Gambar 2. Grafik Uji Normalitas

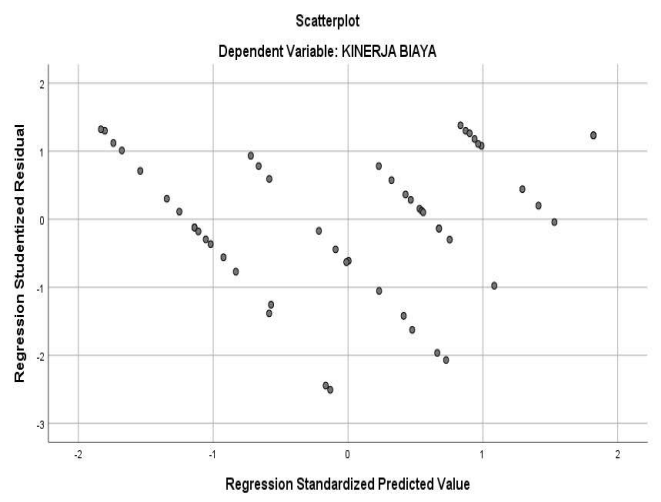

Gambar 3. Titik Heterokedastisitas

Asumsi klasik uji auto korelasi run test Nilai Asymp. Sig. (2-tailed) adalah kriteria untuk membuat keputusan artinya, tidak ada gejala autokorelasi jika $>0,05$ [12]. Hasil riset ini didapatkan nilai Asymp. Sig. (2-tailed) yaitu 0,575 > 0,05, pada riset ini menyatakan bahwa tidak ada auto korelasi, sehingga pengujian pada regresi linier berganda, dapat dilanjutkan. Resume riset pada Tabel 4.

Analisis dari riset dengan menggunakan program SPSS, dapat diketahui bahwa, pada Coeffcients ${ }^{\alpha}$ atau Tabel 3, didapatkan suatu model matematika adalah :

$$
\mathrm{Y}=-2,864+0,088 \mathrm{X} 1+0,131 \mathrm{X} 2+0,057 \mathrm{X} 3+0,103 \mathrm{X} 4
$$

Interpretasi persamaan model matematika dari regresi liner berganda diatas adalah : 
a. Persamaan model matematika diatas menunjukan bahwa variabel $\mathrm{Y}$ sebagai variabel yang menunjukan peningkatan biaya kontraktor sangat di pengaruhi, variabel X.1 (dokumen kontrak), X.2 (stakeholder), X.3 (desain), X.4 (konstruksi) persamaan tersebut menggambarkan terjadinya "trend" atas persepsi responden, terhadap pada pernyataan yang ada di riset ini. Trend ini menunjukkan kearah positif yang di mulai dengan angkat konstant sebesar - 2,864.

b. Variabel X.1 yaitu faktor dokumen kontrak memiliki pengaruh positif terhadap kinerja biaya yang ditunjukan tren grafik yang naik. Artinya "Jika variabel independen dokumen kontrak X.1 memiliki temuan bahwa terjadi spesifikasi teknis yang tidak tertuang, terjadi spesifikasi teknis yang tidak dituangkan jelas pada RKS, bill of quantity dan gambar tender, selain itu juga terjadi penambahan atau pengurangan item pekerjaan, terjadi item pekerjaan tambah tidak tercantum dalam kontrak dan proses pengadaan yang buruk, maka akan memberikan pengaruh positif terhadap kinerja biaya (meningkatkan kinerja biaya) pada pekerjaan jalan tol"

c. Variabel X.2 yaitu faktor stakeholder memiliki penaruh positif terhadap kinerja biaya yang ditunjukan tren grafik yang naik. Artinya "Jika variabel independen stakeholder X.2 memiliki temuan bahwa terjadi permintaan pemilik proyek (owner) untuk optimalisasi fungsi bangunan, selain itu terjadi pemilik menginstruksikan pekerjaan tambahan, dan terjadinya keterlambatan owner dalam memberikan persetujuan gambar, desain kontrak dan klarifikasi, maka akan memberikan pengaruh positif terhadap kinerja biaya (meningkatkan kinerja biaya) pada pekerjaan jalan tol"

d. Variabel X.3 yaitu faktor desain memiliki pengaruh positif terhadap kinerja biaya yang ditunjukan tren grafik yang naik. Artinya "Jika variabel independen desain X.3 memiliki temuan bahwa terjadi ketidak sesuaian antara gambar dan kondisi lapangan, terjadi detail gambar tender awal yang kurang lengkap/ kurang jelas, terjadi perubahan desain / design changes, perbedaan volume yang cukup signifikan antara gambar, kondisi lapangan dan bill of quantity, dan keterlambatan dalam persetujuan shopdrawing oleh pihak konsultan dan owner, maka akan memberikan pengaruh positif terhadap kinerja biaya (meningkatkan kinerja biaya) pada pekerjaan jalan tol"

e. Variabel X.4 yaitu faktor konstruksi memiliki pengaruh positif terhadap kinerja biaya yang ditunjukan tren grafik yang naik. Artinya "Jika variabel independen konstruksi X.4 memiliki temuan bahwa terjadi modifikasi spesifikasi material, perubahan cakupan / scope changes, kesalahan dalam menghitung estimasi volume, dan naikkan harga kontrak, maka akan memberikan pengaruh positif terhadap kinerja biaya (meningkatkan kinerja biaya) pada pekerjaan jalan tol"

Tabel 4 . Uji Auto Korelasi Run Test

\begin{tabular}{lr}
\hline & Unstandardized \\
& Residual \\
\hline Test Valuea & .05762 \\
Cases $<$ Test Value & 26 \\
Cases $>=$ Test Value & 26 \\
Total Cases & 52 \\
Number of Runs & 29 \\
Z & .560 \\
Asymp. Sig. (2-tailed) & .575 \\
\hline
\end{tabular}

a. Median

Berdasarkan koefisien determinasi, yaitu pada Tabel 5, nilai R Square adalah 0,809. Riset perhitungan statistik berarti pengaruh dari variabel independent yaitu dokumen kontrak, stakeholder, desain, dan kontruksi (X.1, X.2, X.3, dan X.4) dalam menerangkan perubahan variabel dependen ialah variabel kinerja peningkataan biaya $(\mathrm{Y})$ yaitu sebesar $80,9 \%$ sisanya $19,1 \%$ didapat dari luar model variabel, pada regresi yang telah dianalisis.

Pengujian Hipotesis

Riset yang telah dilakukan yaitu mendapatkan persamaan model matematika dan nilai R Square, selanjutnya dapat melakukan pengujian hipotesis. Pada riset yang dilakukan pengujijan hipotesis dilakukan dengan 2 (dua) cara yaitu pengujian $\mathrm{T}-$ tes dan pengujian $\mathrm{F}-$ tes.

a. Pengujian $\mathrm{T}$ - tes

Untuk nilai Sig. $<0,05$ artinya variabel independent (X) berpengaruh secara parsial terhadap variabel dependent (Y) sesuai dengan nilai Hitung dan Tabel [12]. Apabila nilai Thitung $>$ T-tabel maka variabel Independent $(\mathrm{X})$ dapat mempengaruhi secara parsial terhadap variabel dependent (Y), sedangkan jika nilai T-hitung $<$ T-tabel merupakan variabel Independent, artinya tidak akan berpengaruh secara parsial terhadap variabel dependent (Y) [13].

Hipotesis untuk kasus pengujian $\mathrm{T}$ - tes adalah :

$\mathrm{H}_{\mathrm{O}}: \mathrm{b}_{\mathrm{y} 1}=0$, Variabel X.1 tidak berpengaruh terhadap variabel $\mathrm{Y}$

$\mathrm{H}_{1}: \mathrm{b}_{\mathrm{y} 1} \neq 0$, Variabel X.1 berpengaruh terhadap variabel $\mathrm{Y}$ $\mathrm{H}_{\mathrm{O}}: \mathrm{b}_{\mathrm{y} 2}=0$, Variabel X.2 tidak berpengaruh terhadap variabel $\mathrm{Y}$

$\mathrm{H}_{1}: \mathrm{b}_{\mathrm{y} 2} \neq 0$, Variabel X.2 berpengaruh terhadap variabel $\mathrm{Y}$

$\mathrm{H}_{\mathrm{O}}: \mathrm{b}_{\mathrm{y} 3}=0$, Variabel X.3 tidak berpengaruh terhadap variabel $\mathrm{Y}$

$\mathrm{H}_{1}: \mathrm{b}_{\mathrm{y} 3} \neq 0$, Variabel X.3 berpengaruh terhadap variabel $\mathrm{Y}$

Ho : $b_{y} 4=0$, Variabel X.4 tidak berpengaruh terhadap variabel Y 
$\mathrm{H}_{1}$ : $\mathrm{by}_{4} \neq 0$, Variabel $\mathrm{X} .1$ berpengaruh terhadap variabel $\mathrm{Y}$

Rumus mencari T-tabel

T-tabel : T $(\alpha / 2: \mathrm{n}-\mathrm{k}-1)$

Keterangan :

$\alpha$ adalah nilai Signifikan standar Statistik $=0,05$

$\mathrm{n}$ adalah jumlah dari sampel riset $=52$

$\mathrm{k}$ adalah jumlah dari variabel $\mathrm{X}=4$

Tingkat kepercayaan digunakan $95 \%=\alpha=0,05$

T-tabel : $\mathrm{T}(\alpha / 2 ; \mathrm{n}-\mathrm{k}-1)=\mathrm{T}(0,05 / 2 ; 52-4-1)=\mathrm{T}$

$(0,025 ; 47)=2.012[12]$.

Riset dari uji-t, dapat diperoleh dari nilai t-hitung sesuai dengan ketentuan yang merupakan hasil hipotesis penelitia$n$ pada Tabel $6>$ uji t-tabel $(\mathrm{t}=2,012)$. Tolak Ho akan tetapi $\mathrm{H} 1$ diterima, penjelasannya adalah contract change order merupakan faktor yang berdampak signifikan terhadap biaya kontraktor.

b. Pengujian F - tes

Riset hipotesis yang dilakukan menggunakan F-test. Uji F-test pada dasarnya semua variabel adalah independen yang terdapat dalam model matematika yang memiliki pengaruh terhadap variabel terikat/dependen [12].

-Hipotesis:

Hipotesis pada pengujian F-tes adalah:

Ho : by $_{1234}=0$, variabel $Y$ tidak dipengaruhi oleh variabel $\mathrm{X}$

$\mathrm{H}_{1}$ : by $_{1234} \neq 0$, yang artinya pengaruh variabel $\mathrm{X}$ terhadap variabel secara bersama-sama. Y

-Menentukan F-tabel dan F-hitung

Fase signifikansi, yaitu 5\% $(\alpha=0,05)$ dengan degree of freedom: didapat numerator adalah 4 , dan denumerator adalah 47, lihat Tabel 7. Jika nilai dari F-hitung $>$ F-tabel artinya bahwa variabel independent $(\mathrm{X})$ secara simultan berpengaruh terhadap variabel dependent (Y) [13].

F-tabel : $\mathrm{F}(\mathrm{k} ; \mathrm{n}-\mathrm{k})$

Keterangan :

$\mathrm{n}$ adalah jumlah dari sampel riset $=52$

$\mathrm{k}$ adalah jumlah dari variabel $\mathrm{X}=4$

Tingkat kepercayaan digunakan $95 \%=\alpha=0,05$

F-tabel : $\mathrm{F}(\mathrm{k} ; \mathrm{n}-\mathrm{k})=\mathrm{F}(4 ; 52-4)=\mathrm{F}(4 ; 48)=2,56$

(Digunakan N yang terdekat) [12].

- Dengan membandingkan Ftabel dan Fhitung

F-hitung $>$ F-tabel, berarti Ho tolak

F-hitung $<$ F-tabel, berarti Ho diterima

Berdasarkan penelusuran yang dilakukan, F-hitung yang diperoleh pada Tabel 7 (49,682), lebih besar dari F-tabel $(2,56)$ dan diperoleh hasil yang signifikan 0,000 , artinya Ho ditolak, sedangkan H1 diterima. Selanjutnya dapat dilihat bahwa signifikan $<0.05$ maka Ho ditolak sedangkan $\mathrm{H} 1$ diterima. Berdasarkan hasil riset diatas didapatkan bahwa, nilai F-hitung 49,682 > 2,56 F-tabel dan signifikan adalah $0,000<$ dari 0,05 . Model regresi dari riset didapatkan secara simultan bahwa berpengaruh terhadap Y.

Pembahasan

1. Faktor yang menjadi penyebab terjadinya contract change order pada proyek jalan tol

Penyebab terjadinya contract change order pada riset ini terdiri beberapa faktor diantaranya yaitu faktor pertama dokumen kontrak (X.1), faktor kedua stakeholder (X.2), faktor ketiga desain (X.3), dan faktor keempat konstruksi (X.4). Riset yang telah dilakukan oleh peneliti menggunakan pengujian validitas, realibilitas, asumsi klasik, regresi linier berganda, dan dilakukan uji hipotesis uji t, uji f. Pengujian tersebut didapatkan semua variabel faktor dokumen kontrak, stakeholder, desain, dan konstruksi menjadi faktor penyebab contract change order. Hal ini juga didukung oleh riset terdahulu yang telah dilakukan.

Faktor dokumen kontrak (X.1) yaitu berdasarkan riset unsur-unsur yang menyebabkan contract change order selama pembangunan, yang dominan meliputi spesifikasi yang tidak lengkap, dan informasi rinci dalam dokumen yang tidak jelas [3]. Penyebab signifikan salah satunya benturan antara dokumen kontrak yang menyebabkan menambah atau mengurangi item pekerjaan dan item pekerjaan tambahan yang tidak tercantum dalam kontrak [5]. Penyebab lain diantaranya pengadaan yang buruk dan item pekerjaan tambah tidak tercantum dalam kontrak menjadi temuan baru pada riset ini. Hasil riset terdahulu ini mendukung penelitian yang telah dilakukan oleh peneliti bahwasannya persepsi atau sudut pandang dari responden mengenai faktor variabel X.1 yaitu dokumen kontrak menjadi salah satu penyebab terjadinya pekerjaan tambah kurang/contract change order pada pelaksanaan pembangunan jalan tol dan juga memiliki pengaruhnya terhadap kinerja peningkatan biaya.

Faktor stakeholder (X.2) yaitu berdasarkan hasil riset terdahulu menyebutkan bahwa faktor utama contract change order adalah perubahan dari owner untuk optimalisasi fungsi bangunan dan pemilik menginstruksikan untuk melakukan pekerjaan tambahan [8]. Selain itu pada riset yang lain menyebutkan bahwa salah satu penyebab contract change order yaitu kompleksitas pada desain yaitu keterlambatan pada owner untuk menyetujui gambar, serta desain kontrak, dan klarifikasi [3]. Hasil riset terdahulu ini mendukung penelitian yang telah dilakukan oleh peneliti bahwasannya persepsi atau sudut pandang dari responden mengenai faktor variabel X.2 yaitu stakeholder menjadi salah satu penyebab terjadinya pekerjaan tambah kurang/contract change order 
pada pelaksanaan pembangunan jalan tol dan juga memiliki pengaruhnya terhadap kinerja peningkatan biaya.

Faktor desain (X.3) yaitu berdasarkan riset terdahulu menyebutkan bahwa pekerjaan peningkatan jalan pada lokasi pasar panas-bentot 2 (multiyears) terjadinya contract change order yang disebabkan oleh ketidaksesuaian antara gambar dan situasi di lapangan [16]. Riset lain yang mendukung faktor desain (X.3) diantaranya yaitu riset yang telah dilakukan oleh Gumolili menyebutkan hasil penelitian menunjukkan bahwa faktor penyebab change order yang dominan salah satunya detail gambar yang tidak jelas [3], riset lain menurut Hardjomuljadi menyebutkan konsekuensi mengikuti terbitnya change order adalah faktor perubahan desain [14], selain itu pada faktor observasi riset yaitu ada perbedaan yang signifikan dalam volume antara gambar, kondisi situasi dan daftar kuantitas, dan keterlambatan dalam persetujuan shopdrawing oleh pihak konsultan dan owner. Hasil riset terdahulu ini mendukung penelitian yang telah dilakukan oleh peneliti bahwasannya persepsi atau sudut pandang dari responden mengenai faktor variabel X.3 yaitu desain menjadi salah satu penyebab terjadinya pekerjaan tambah kurang/contract change order pada pelaksanaan pembangunan jalan tol dan juga memiliki pengaruhnya terhadap kinerja peningkatan biaya.

Faktor kontruksi (X.4) yaitu berdasarkan riset terdahulu menyebutkan bahwa dari modifikasi spesifikasi material dapat menyebabkan terjadinya contract change order [8]. Riset terdahulu menyebutkan melalui survei kuesioner, studi tersebut menyimpulkan bahwa salah satu dari lima penyebab paling umum dari perubahan pesanan dapat diidentifikasi sebagai: perubahan lingkup proyek [15]. Berdasarkan riset terdahulu menyebutkan bahwa pekerjaan peningkatan jalan pada lokasi pasar panas-bentot 2 (multiyears) terjadinya contract change order yang disebabkan oleh kesalahan dalam menghitung estimasi volume [16], selain itu juga pada riset terdahulu yang lain juga menyebutkan bahwa salah satu terjadinya contract change order seperti estimasi yang buruk [17]. Riset yang dilakukan terdahulu menyebutkan terbitnya contract change order adalah naikkan harga kontrak [14]. Hasil riset terdahulu ini mendukung penelitian yang telah dilakukan oleh peneliti bahwasannya persepsi atau sudut pandang dari responden mengenai faktor variabel X.4 yaitu konstruksi menjadi salah satu penyebab terjadinya pekerjaan tambah kurang/contract change order pada pelaksanaan pembangunan jalan tol serta memiliki pengaruhnya terhadap kinerja peningkatan biaya.

2. Faktor yang berpengaruh dominan pekerjaan contract change order terhadap kinerja biaya pekerjaan jalan tol.
Uji T-test dengan menggunakan program SPSS pada faktor konstruksi yang telah dilakukan menunjukan hasil riset signifikasi, diperoleh $0.007<$ signifikasi $(\alpha=0.05)$, Tabel 5 menjelaskan, bahwa koefisien regresi adalah 0,103 , dan nilai jika $\mathrm{T}-$ hitung $=2,830($ dari Tabel 5) $>\mathrm{T}-$ tabel $=$ 2,012 (dari $\mathrm{T}$ - tabel), riset ini dapat disimpulkan bahwa faktor konstruksi secara parsial ditemukan adanya pengaruh dominan terhadap kinerja biaya pada pembagunan jalan tol.

Riset terdahulu menyebutkan konstruksi adalah suatu rangkaian kegiatan yang mempunyai keterbatasan terhadap waktu yang telah dikesepakati bersama antara pengguna jasa dengan penyedia jasa [2]. Riset terdahulu menyebutkan juga bahwa dari modifikasi spesifikasi material menyebabkan terjadinya contract change order [8]. Faktor tersebut dikelompokan didalam indikator pada faktor konstruksi yaitu X.4.3. Berdasarkan riset terdahulu menyebutkan melalui survei kuesioner, studi tersebut menyimpulkan bahwa salah satu dari lima penyebab paling umum dari perubahan pesanan dapat diidentifikasi sebagai: perubahan lingkup proyek [15]. Penyebab tersebut dikelompokan didalam indikator pada faktor konstruksi yaitu X.4.4. Berdasarkan riset terdahulu menyebutkan bahwa pekerjaan peningkatan jalan pada lokasi pasar panas-bentot 2 (multiyears) terjadinya contract change order yang disebabkan oleh kesalahan dalam menghitung estimasi volume [16], selain itu juga pada riset terdahulu yang lain juga menyebutkan bahwa salah satu terjadinya contract change order seperti estimasi yang buruk hal ini lah yang mengakibatkan terjadinya peningkatan kinerja biaya diluar perkiraan kontraktor [17]. Penyebab tersebut dimasukan kedalam indikator X.4.5. Riset yang dilakukan terdahulu menyebutkan terbitnya contract change order adalah naikkan harga kontrak [14], penyebab tersebut dimasukan kedalam indikator X.4.6.

Berdasarkan riset terdahulu ini mejadi pendukung untuk riset yang telah dilakukan oleh peneliti, selain itu juga diperkuat temuan riset yang dilakukan oleh peneliti bahwa faktor konstruksi memliki pengaruh positif terhadap kinerja biaya pembangunan jalan tol.

3. Pengaruh konstruksi, stakeholder, dokumen kontrak, dan desain dari contract change order terhadap biaya pada pembangunan jalan tol

Uji F-test dengan menggunakan program SPSS yang telah dilakukan menunjukan hasil signifikasi, 0.000 lebih kecil dari signifikasi $(\alpha=0.05)$ dan nilai F-hitung $=49,682$ (Tabel 7) lebih besar dari F-tabel 2,56 (dari F-tabel), maka dapat disimpulkan bahwa pekerjaan contract change order yang terdiri dari faktor dokumen kontrak, stakeholder, desain, dan konstruksi secara simultan sangat mempengaruhi 
terhadap kinerja biaya pada pekerjaan jalan tol proyek strategis nasional (psn) sebesar $80,9 \%$ sisanya $19,1 \%$ didapat dari luar model variabel, pada regresi yang telah dianalisis. Hal ini mendukung riset terdahulu yaitu termasuk dampak besarnya pengaruh yang diberikan contract change order terhadap biaya ialah $36,3 \%$ [6].

\section{Simpulan}

Berdasarkan hasil riset pada pembahasan dan analisis, dapat dirangkum menjadi kesimpulan:

1. Faktor yang menjadi penyebab terjadinya contract change order pada proyek jalan tol secara berurutan diantaranya faktor konstruksi, stakeholder, dokumen kontrak, dan desain.

2. Faktor yang berpengaruh dari contract change order terhadap kinerja biaya kontraktor pada pelaksanaan pekerjaan konstruksi jalan tol proyek strategis nasional yaitu faktor konstruksi, stakeholder, dokumen kontrak, dan desain. Faktor dominan yang berpengaruh yaitu variabel konstruksi yang terlihat pada uji $\mathrm{T}$ hitung yaitu sebesar sebesar 2,830, probabilitas terkecil / signifikan yaitu 0,007, dan koefisien regresi sebesar 0,103. Riset terdahulu menyebutkan bahwa salah satu terjadinya contract change order, terutama selama tahap konstruksi suatu proyek seperti estimasi yang buruk hal ini lah yang mengakibatkan terjadinya peningkatan kinerja biaya diluar perkiraan kontraktor [17]. Pengujian yang telah dilakukan mendapatkan hasil dominan yaitu sebesar 2,830 , probabilitas terkecil / signifikan yaitu 0,007 . Hal tersebut dapat diketahui bahwa Variabel X.4 yaitu faktor konstruksi memiliki pengaruh positif terhadap kinerja biaya yang ditunjukan tren grafik yang naik. Artinya "Jika variabel independen konstruksi X.4 memiliki temuan bahwa terjadi modifikasi spesifikasi material, perubahan cakupan / scope changes, kesalahan dalam menghitung estimasi volume, dan naikkan harga kontrak, maka akan memberikan pengaruh positif terhadap kinerja biaya (meningkatkan kinerja biaya) pada pekerjaan jalan tol."

3. Riset yang telah dilakukan terdapat pekerjaan tambah kurang/contract change order secara simultan sangat mempengaruhi terhadap kinerja biaya pada pekerjaan jalan tol proyek strategis nasional (psn) sebesar 80,9\% sisanya $19,1 \%$ didapat dari luar model variabel, pada regresi yang telah dianalisis. Hal ini mendukung riset terdahulu yaitu termasuk dampak besarnya pengaruh yang diberikan contract change order terhadap biaya ialah $36,3 \%$ [6].

\section{Daftar Pustaka}

[1] F. Kristiawan, M. A. Rohman, and Machsus, "A Framework to Assess Success Criteria Performance of Public Private Partnership (PPP) Toll Road Projects in Indonesia," IOP Conf. Ser. Mater. Sci. Eng., vol. 930, no. 1. 2020.

[2] Martanti, Ana Yuni. "Pengaruh Contract Change Order terhadap Pembiayaan Kontraktor pada Proyek Konstruksi Pemerintah". Tesis. Program Studi Magister Manajmen, Program Pascasarjana. Universitas Mercu Buana. Jakarta. 2018.

[3] Gumolili, S., Sompie, B., \& Rantung, J. “Analisa Faktor-Faktor Penyebab Change Order dan Pengaruhnya terhadap Kinerja Waktu Pelaksanaan Proyek Konstruksi di Lingkungan Pemerintah Provinsi Sulawesi Utara". Jurnal Ilmiah Media Engineering, 2(4), 98522. 2012.

[4] Ardine, A. A., \& Sulistio, H. "Penyebab Change Order pada Proyek Konstruksi Gedung Bertingkat". JMTS: Jurnal Mitra Teknik Sipil. 2020.

[5] Wali, K. I., \& Saber, N. I. "An Analysis of Causes and Factors Affecting Change Orders Occurrence in Construction Projects in Iraq". Zanco Journal Of Pure And Applied Sciences, 31(6). 2019.

[6] Beatrix, M., \& Wiguna, I. putu A. "Analisa Pengaruh Change Order terhadap Biaya, Waktu dan Mutu Proyek Konstruksi di Surabaya". Jurnal Riset Teknik Sipil Institut Teknologi Sepuluh Nopember, 1-7. 2014.

[7] Memon, A. H., Rahman, I. A., \& Hasan, M. F. A. "Significant Causes and Effects of Variation Orders in Construction Projects". Research Journal of Applied Sciences, Engineering and Technology, 7(21), 4494-4502. 2014.

[8] Assbeihat, J. M., \& Sweis, G. J. "Factors Affecting Change Orders in Public Construction Projects". International Journal of Applied Science and Technology, 5(6), 56-63". 2015.

[9] Cathelina, Seira Diwama. "Analisis Pengaruh Contract Change Order terhadap Biaya dan Waktu". Skripsi. Program Studi Teknik Sipil, Fakultas Teknik. Universitas Mercu Buana. Jakarta. 2019.

[10] Ade Permana, A., Firdaus, M., \& Dimyati, M. "Pengaruh Komitmen, Komunikasi dan Penanganan Masalah terhadap Kepercayaan Nasabah pada Bank Jatim Cabang Banyuwangi". Relasi : Jurnal Ekonomi. 2020.

[11] Zano, B. R., \& Santoso, T. "Analisis Pengaruh Kualitas Produk, Harga dan Iklan Terhadap 
Keputusan Pembelian Sepeda Motor Yamaha. Agora", 7(1). 2019.

[12] Ghozali, Imam. "Aplikasi Analisis Multivariate dengan Program Spss", Badan Pernerbit Universitas Diponegoro. Semarang. 2011.

[13] Sujarweni, V. Wiratna. "SPSS untuk Riset". Pustaka baru press. Yogyakarta. 2014.

[14] Hardjomuljadi, S. "Variation Order, The Causal or The Resolver of Claims and Disputes in The Construction Projects". International Journal of Applied Engineering Research, 11(14), 8128-8135. 2016.

[15] Mahamid, I. "Effect of Change Orders on Rework in Highway Projects in Palestine". Journal of Financial
Management of Property and Construction, 22(1), 62-76. 2017.

[16] Prayudi, A. "Penyebab dan Pengaruh Contract Change Order pada Proyek Peningkatan Jalan (Studi Kasus Paket Kegiatan Jalan Pasar Panas-Bentot 2 Multiyears)". Jurnal Teoritis Dan Terapan Bidang Keteknikan, 1, 11-19. 2017.

[17] Shrestha, P. P., \& Maharjan, R. "Effects of Change Orders on Cost Growth, Schedule Growth, and Construction Intensity of Large Highway Projects". Journal of Legal Affairs and Dispute Resolution in Engineering and Construction, 10(3), 04518012. 2018.

Tabel 3. Asumsi Klasik Uji Multikolinieritas dan Uji Regresi Linier Berganda

\begin{tabular}{|c|c|c|c|c|c|c|c|c|}
\hline \multicolumn{9}{|c|}{ Coefficients $^{a}$} \\
\hline & \multirow[t]{3}{*}{ Model } & \multirow{2}{*}{\multicolumn{2}{|c|}{$\begin{array}{l}\text { Unstandardized } \\
\text { Coefficients }\end{array}$}} & \multirow{3}{*}{$\begin{array}{l}\text { Standardized } \\
\text { Coefficients } \\
\text { Beta }\end{array}$} & \multirow[t]{3}{*}{$\mathrm{t}$} & \multirow[t]{3}{*}{ Sig. } & \multirow{2}{*}{\multicolumn{2}{|c|}{ Collinearity Statistics }} \\
\hline & & & & & & & & \\
\hline & & B & $\begin{array}{l}\text { Std. } \\
\text { Error }\end{array}$ & & & & Tolerance & VIF \\
\hline \multirow[t]{5}{*}{1} & (Constant) & -2.864 & .419 & & -6.833 & .000 & & \\
\hline & Dokumen Kontrak & .088 & .039 & .256 & 2.241 & .030 & .312 & 3.202 \\
\hline & Stakeholder & .131 & .055 & .249 & 2.384 & .021 & .374 & 2.675 \\
\hline & Desain & .057 & .027 & .245 & 2.162 & .036 & .316 & 3.160 \\
\hline & Konstruksi & .103 & .036 & .280 & 2.830 & .007 & .416 & 2.404 \\
\hline
\end{tabular}

a. Dependent Variable: Kinerja Biaya

Tabel 5. Uji Koefisien Determinasi R Square

\begin{tabular}{lllll}
\hline Model & $\mathrm{R}$ & $\begin{array}{c}\text { Model Summary }^{\mathbf{b}} \\
\text { R Square }\end{array}$ & $\begin{array}{l}\text { Adjusted } \\
\text { Square }\end{array}$ & $\mathrm{R}$ \\
\hline 1 & $.899^{\mathrm{a}}$ & .809 & .792 & $\begin{array}{l}\text { Std. Error of } \\
\text { the Estimate }\end{array}$ \\
\hline
\end{tabular}

a. Predictors: (Constant), Konstruksi, Dokumen Kontrak, Stakeholder, Desain

b. Dependent Variable: Kinerja Biaya

Tabel 6. Uji T

\begin{tabular}{|c|c|c|c|c|c|c|}
\hline \multicolumn{7}{|c|}{ Coefficients $^{\mathrm{a}}$} \\
\hline & \multirow[t]{3}{*}{ Model } & \multirow{2}{*}{\multicolumn{2}{|c|}{$\begin{array}{l}\text { Unstandardized } \\
\text { Coefficients }\end{array}$}} & \multirow{3}{*}{$\begin{array}{l}\text { Standardized } \\
\text { Coefficients } \\
\text { Beta }\end{array}$} & \multirow[t]{3}{*}{$\mathrm{t}$} & \multirow[t]{3}{*}{ Sig. } \\
\hline & & & & & & \\
\hline & & B & $\begin{array}{l}\text { Std. } \\
\text { Error }\end{array}$ & & & \\
\hline \multirow[t]{5}{*}{1} & (Constant) & -2.864 & .419 & & -6.833 & .000 \\
\hline & Dokumen Kontrak & .088 & .039 & .256 & 2.241 & .030 \\
\hline & Stakeholder & .131 & .055 & .249 & 2.384 & .021 \\
\hline & Desain & .057 & .027 & .245 & 2.162 & .036 \\
\hline & Konstruksi & .103 & .036 & .280 & 2.830 & .007 \\
\hline
\end{tabular}

a. Dependent Variable: Kinerja Biaya 
Tabel 7. Uji F

\begin{tabular}{lllllll}
\hline & & \multicolumn{5}{c}{ ANOVA $^{\mathbf{a}}$} \\
& Model & Sum of Squares & df & Mean Square & F & Sig. \\
\hline 1 & Regression & 62.630 & 4 & 15.657 & 49.682 & $.000^{\mathrm{b}}$ \\
& Residual & 14.812 & 47 & .315 & & \\
Total & 77.442 & 51 & & & \\
\hline
\end{tabular}

a. Dependent Variable: Kinerja Biaya

b. Predictors: (Constant), Konstruksi, Dokumen Kontrak, Stakeholder, Desain 